Article

\title{
Assessment of Antioxidant Properties of Classic Energy Drinks in Comparison with Fruit Energy Drinks
}

\author{
Dariusz Nowak * and Michał Gośliński \\ Department of Nutrition and Dietetics, Faculty of Health Sciences, Ludwik Rydygier Collegium Medicum in \\ Bydgoszcz, Nicolaus Copernicus University in Toruń, Dębowa 3, 85-626 Bydgoszcz, \\ Poland; m.goslinski@cm.umk.pl \\ * Correspondence: d.nowak@cm.umk.pl
}

Received: 17 November 2019; Accepted: 22 December 2019; Published: 7 January 2020

\begin{abstract}
Energy drinks (EDs) contain sugar, caffeine, and other bioactive compounds. Recently, new types of EDs, enriched with fruit juices, natural pigments, and plant extracts, have been launched in the market. The objective of this study was to investigate the composition and antioxidant properties of the most popular classic and fruit EDs. The study was carried out including 24 of the most popular energy drinks (classic and fruit EDs). The composition of EDs, especially caffeine and sugar, and antioxidant properties (antioxidant capacity, total polyphenols, total anthocyanins, vitamin C) were analyzed. Energy drinks with added fruit juice or natural pigments had a significantly higher $(p \leq 0.05)$ antioxidant capacity compared to classic energy drinks. Fruit EDs had a higher concentration of polyphenols and vitamin C. In some fruit EDs, slight amounts of anthocyanins were found. Generally, EDs are not a rich source of polyphenols and are not distinguished by high antioxidant capacity. However, fruit energy drinks and/or ones with added natural pigments have much better antioxidant properties than classic EDs. Both classic and fruit EDs contain a large amount of caffeine and sugar, therefore, it would be advisable not to drink large amounts of EDs for possible related health issues.
\end{abstract}

Keywords: energy drinks; antioxidant properties; vitamin C; sugar

\section{Introduction}

Energy drinks (EDs) are very popular among adolescents and young adults. A classic ED usually contains water, sugar, pigments, acidity regulator (e.g., citric acid or sodium citrate), and caffeine as well as other bioactive compounds, such as taurine, guarana extract, inositol, glucuronolactone, vitamins, mostly $B$ ones (niacin, pantothenic acid, vitamins $B_{6}$ and $B_{12}$ ) [1-3]. Some EDs also have a preservative in their composition, e.g., sodium benzoate or potassium sorbate. EDs are also sold as sugar-free drinks or ones with added fruit juice or natural pigments (e.g., anthocyanins, carotenoids). A typical ED contains about $320 \mathrm{mg} / \mathrm{Kg}$ of caffeine, and other ingredients, which may have negative effects on human health, come in different amounts [4]. Caffeine is the substance whose excessive and long-term consumption is well known to raise the blood pressure and pulse rate, as well as causing higher aggregation of blood platelets and inferior function of the endothelium [5-8]. On the other hand, some studies indicate that caffeine intake (below $600 \mathrm{mg} /$ day) causes mild, transient and reversible, cardiovascular effects, without lasting adverse effects [9]. Other researchers have shown that acute ingestion of coffee may result in favorable changes to markers of cardiometabolic health [10]. Moderate caffeine intake should also not affect bone mineral density (BMD) [11]. Furthermore, excessive consumption of energy drinks due to the interaction of caffeine and sugar causes adverse changes in cardiovascular system [12,13]. 
The literature provides ample data to support the antioxidant capacity of fruit, vegetables, and fruit juices. The health beneficial effects of fruits and fruit juices are mainly attributed to the presence of bioactive compounds such as polyphenols, mostly flavonoids (including anthocyanins), carotenoids, ascorbic acid, etc. [14-16]. It has not been verified yet whether energy drinks have sufficient antioxidant capacity to reduce oxidative stress. It is known that some ingredients, like taurine or ginseng, if present in adequate amounts, can demonstrate antioxidant properties $[17,18]$.

The intense marketing of producers of energy drinks influences the nutritional behavior of adolescents and young adults. The consumption of energy drinks is growing. On the other hand, we know more about the health risks associated with the consumption of energy drinks. High content of caffeine and sugar is a problem, but on the other hand, in new versions of these drinks, there are fruit juices, vitamins, and plant extracts. The presence of polyphenolic compounds or vitamin $C$ in EDs enriched with fruit juices can enhance the antioxidant capacity of these beverages, but this assumption needs verification. What is lacking as well is the research demonstrating whether other additives in a typical ED have antioxidant properties. Therefore, the objective of this study has been to analyze the antioxidant properties of fruit energy drinks and to compare them with classic EDs.

\section{Materials and Methods}

\subsection{Materials}

The study comprised 24 types of EDs purchased in local supermarkets. Ten samples were EDs with added fruit juice or natural pigments, e.g., anthocyanins (fruit EDs), while 14 samples were popular, classic EDs (Table 1). The classic EDs (C1-C14) most often contained $320 \mathrm{mg} / \mathrm{Kg}$ of caffeine (except C11), 100-110 g/Kg of sugar (saccharose), or glucose-fructose syrup (except C12 and C13, i.e., sugar-free EDs, with aspartame, acesulfame K, sucralose), acidity regulator (citric acid, sodium citrate), carbon dioxide, taurine, inositol, pigments (E150c, E150d, and E101), flavorings, sometimes guarana and glucuronolactone (only C11), as well as group B vitamins (most often niacin, pantothenic acid, vitamins $B_{6}$ and $B_{12}$ ). Besides these ingredients, fruit EDs added with different types of fruit juices contained slightly more sugar, i.e., 110-150 g/Kg (except F8), and other compounds such as citric or malic acid and natural pigments (anthocyanins or carotenoids).

In addition, fruit EDs contained often ginseng extract and guarana (details in Table 1). Prior to analyses, the EDs samples were stored in original containers (cans) at room temperature.

\subsection{Methods}

The $\mathrm{pH}$ of the tested samples of EDs was measured with a glass electrode (Hanna Instruments, Olsztyn, Poland) at room temperature.

\subsection{Soluble Solids Content}

The soluble solids content of samples was measured with a laboratory refractometer RL-3 (PZO, Warsaw, Poland), at $20^{\circ} \mathrm{C}$, similarly to the method used by Rubio-Arraez et al. [19].

\subsection{Analysis of Vitamin $C$}

The total vitamin C content was determined according to Polish Norm PN-A-04019:1998 [20] as previously described by Hallmann et al. [21]. A weighed juice sample was extracted in $2.0 \%$ oxalic acid. The solution was filtered. The filtrate was collected and then titrated with the 2.6-dichlorophenyloindophenol (Avantor Performance Materials, Gliwice, Poland) [20,21]. The results were expressed as milligrams of ascorbic acid (AA) per kilogram of sample. 
Table 1. Characteristics of the analyzed energy drinks.

\begin{tabular}{|c|c|c|c|c|c|c|c|c|}
\hline Sample & Kind of ED & $\begin{array}{l}\text { Standard } \\
\text { Ingredients }\end{array}$ & Extra Ingredients & $\begin{array}{c}\text { Energy Per } 100 \\
\text { mL (Kj) }\end{array}$ & $\begin{array}{l}\text { Declared } \\
\text { Caffeine } \\
\text { Content } \\
(\mathrm{mg} / \mathrm{Kg})\end{array}$ & $\begin{array}{c}\text { Declared } \\
\text { Sugar } \\
\text { Content } \\
(\mathrm{g} / \mathrm{Kg})\end{array}$ & $\mathrm{pH}$ & $\begin{array}{l}\text { Soluble Solids } \\
\text { Content }(\mathrm{g} / \mathrm{Kg})\end{array}$ \\
\hline $\mathrm{C} 1$ & classic & \multirow{13}{*}{$\begin{array}{c}\text { taurine, } \\
\text { inositol, } \\
\text { niacin, } \\
\text { pantothenic } \\
\text { acid, } \\
\text { vitamin } \mathrm{B}_{6}, \mathrm{~B}_{12} \text {, } \\
\text { acidity regulator } \\
\text { (sodium citrate } \\
\text { and/or citric } \\
\text { acid) }\end{array}$} & - & 192.6 & 320 & 108 & $3.35^{c}$ & $117.5^{\mathrm{b}}$ \\
\hline $\mathrm{C} 2$ & classic & & - & 184.2 & 320 & 103 & $3.22^{c, d}$ & $130.0^{\mathrm{b}}$ \\
\hline C3 & classic & & - & 192.6 & 320 & 110 & $3.29^{c}$ & $125.0^{\mathrm{b}}$ \\
\hline $\mathrm{C} 4$ & classic & & - & 192.6 & 320 & 110 & $3.34^{c}$ & $125.0^{\mathrm{b}}$ \\
\hline C6 & classic & & - & 192.6 & 320 & 110 & $3.31^{c}$ & $125.0^{\mathrm{b}}$ \\
\hline $\mathrm{C} 7$ & classic & & - & 184.2 & 320 & 103 & $3.43^{b}$ & $120.0^{\mathrm{b}}$ \\
\hline $\mathrm{C} 8$ & classic & & - & 192.6 & 320 & 110 & $3.30^{c}$ & $120.0^{\mathrm{b}}$ \\
\hline C9 & classic & & - & 188.4 & 320 & 105 & $3.60^{\mathrm{a}}$ & $117.5^{\mathrm{b}}$ \\
\hline $\mathrm{C} 10$ & classic & & Guarana & 192.6 & 320 & 110 & $3.32^{c}$ & $130.0^{\mathrm{b}}$ \\
\hline $\mathrm{C} 11$ & classic & & $\begin{array}{c}\text { guarana, } \\
\text { glucuronolactone }\end{array}$ & 188.4 & 480 & 100 & $3.30^{c}$ & $125.0^{\mathrm{b}}$ \\
\hline $\mathrm{C} 12$ & classic & & - & 12.6 & 320 & $<5$ & $3.18^{\mathrm{d}}$ & $20.0^{c}$ \\
\hline $\mathrm{C} 13$ & classic & & - & 16.7 & 320 & $<1$ & $3.48^{b}$ & $20.0^{c}$ \\
\hline $\mathrm{C} 14$ & classic & & - & 188.4 & 320 & 101 & $3.66^{\mathrm{a}}$ & $120.0^{b}$ \\
\hline $\mathrm{F} 1$ & fruit & \multirow{3}{*}{$\begin{array}{c}\text { taurine, } \\
\text { inositol, } \\
\text { niacin, } \\
\text { pantothenic } \\
\text { acid, } \\
\text { vitamin } \mathrm{B}_{6}, \mathrm{~B}_{12}, \\
\text { acidity regulator } \\
\text { (sodium citrate } \\
\text { and/or citric } \\
\text { acid) }\end{array}$} & $\begin{array}{c}\text { guarana, } \\
\text { anthocyanins, }\end{array}$ & 234.5 & 320 & 133 & $2.73^{\mathrm{e}}$ & $145.0^{\mathrm{a}}$ \\
\hline F2 & fruit & & $\begin{array}{l}\text { ginseng, carotenoids, } \\
\text { pineapple juice }(3 \%)\end{array}$ & 192.6 & 320 & 110 & $2.54^{\mathrm{e}, \mathrm{f}}$ & $125.0^{\mathrm{b}}$ \\
\hline F3 & fruit & & $\begin{array}{c}\text { guarana, juices: apple } \\
(13.8 \%), \text { black currant } \\
(4.3 \%) \text {, grape }(0.9 \%), \\
\text { strawberry }(0.5 \%), \\
\text { raspberry }(0.5 \%), \\
\text { carrot and hibiscus } \\
\text { concentrate }\end{array}$ & 188.4 & 320 & 108 & $3.32^{c}$ & $120.0^{b}$ \\
\hline
\end{tabular}


Table 1. Cont.

\begin{tabular}{|c|c|c|c|c|c|c|c|c|}
\hline Sample & Kind of ED & $\begin{array}{l}\text { Standard } \\
\text { Ingredients }\end{array}$ & Extra Ingredients & $\begin{array}{c}\text { Energy Per } 100 \\
\text { mL (Kj) }\end{array}$ & $\begin{array}{l}\text { Declared } \\
\text { Caffeine } \\
\text { Content } \\
(\mathrm{mg} / \mathrm{Kg})\end{array}$ & $\begin{array}{l}\text { Declared } \\
\text { Sugar } \\
\text { Content } \\
(\mathrm{g} / \mathrm{Kg})\end{array}$ & $\mathrm{pH}$ & $\begin{array}{l}\text { Soluble Solids } \\
\text { Content }(\mathrm{g} / \mathrm{Kg})\end{array}$ \\
\hline $\mathrm{F} 4$ & fruit & & $\begin{array}{c}\text { carotenoids, ascorbic } \\
\text { acid }\end{array}$ & 192.6 & 320 & 110 & $3.27^{c}$ & $125.0^{\mathrm{b}}$ \\
\hline F5 & fruit & & $\begin{array}{l}\text { guarana, ginseng, } \\
\text { apple, and ascorbic } \\
\text { acids }\end{array}$ & 268.0 & 320 & 150 & $2.84^{\mathrm{e}}$ & $160.0^{\mathrm{a}}$ \\
\hline F6 & fruit & & $\begin{array}{l}\text { guarana, apple, and } \\
\text { pomegranate juices, } \\
\text { carrot and hibiscus } \\
\text { concentrate }\end{array}$ & 192.6 & 350 & 110 & $2.39^{\mathrm{f}}$ & $115.0^{\mathrm{b}}$ \\
\hline F7 & fruit & & $\begin{array}{l}\text { guarana, ginseng, } \\
\text { ascorbic acid, } \\
\text { glucuronolactone }\end{array}$ & 251.2 & 320 & 140 & $2.34^{\mathrm{f}}$ & $150.0^{\mathrm{a}}$ \\
\hline F8 & fruit & & $\begin{array}{c}\text { guarana, ginseng, acai, } \\
\text { and goji juices, black } \\
\text { tea extract, } \\
\text { glucuronolactone }\end{array}$ & 41.9 & 320 & 210 & $3.60^{\mathrm{a}}$ & $40.0^{\mathrm{c}}$ \\
\hline F9 & fruit & & $\begin{array}{l}\text { guarana, ginseng, } \\
\text { apple, and citric acids, } \\
\text { glucuronolactone }\end{array}$ & 251.2 & 320 & 140 & $2.32^{f}$ & $145.0^{\mathrm{a}}$ \\
\hline F10 & fruit & & $\begin{array}{l}\text { carotenoids, ascorbic } \\
\text { acid }\end{array}$ & 201.0 & 150 & 130 & $2.80^{\mathrm{e}}$ & $130.0^{\mathrm{b}}$ \\
\hline
\end{tabular}

Different letters in the same column indicate statistical significance (at least $p \leq 0.05$ ); $n=3$. 


\subsection{Antioxidant Capacity by DPPH Assay}

The antioxidant capacity of EDs was determined by a modified Yen and Chen [22] method, using $0.1 \mathrm{~mol} / \mathrm{L}$ methanol solution of 1,1-diphenyl-2-picrylhydrazyl (DPPH, Sigma-Aldrich, St. Louis, MO, USA). This method is widely used to test the antioxidant capacity of fruit, vegetables, juices, and beverages. The advantages of a DPPH assay were previously described [23-25]. A $0.1 \mathrm{~mL}$ of sample was added to $2.9 \mathrm{~mL}$ DPPH solution and mixed. The absorbance was measured on a Hitachi U-1900 spectrophotometer (Hitachi, Tokyo, Japan) at $517 \mathrm{~nm}$ after $30 \mathrm{~min}$ of incubation at room temperature in the dark. Quantification was performed using a Trolox standard curve. The antioxidant capacity of the samples was expressed as milligrams of Trolox equivalents (Tx) per liter of sample.

\subsection{Antioxidant Capacity by ABTS Assay}

The antioxidant capacity of EDs was determined by a Re et al. [26] method with small modifications. In the ABTS method, 2,2' -azinobis-(3-ethyl-benzothiazoline-6-sulfonic acid) diammonium salt (ABTS, Sigma-Aldrich, St. Louis, MO, USA) and potassium persulfate solutions were mixed and stored overnight at room temperature in the dark for 12-16 h. ABTS solution was diluted with methanol to an absorbance of $0.70 \pm 0.02$ at $734 \mathrm{~nm}$.

After addition of $1.0 \mathrm{~mL}$ of diluted ABTS solution $($ A734 $\mathrm{nm}=0.700 \pm 0.020)$ to $0.01 \mathrm{~mL}$ of antioxidant compounds or Trolox standards in methanol, the absorbance was measured at $734 \mathrm{~nm}$ against methanol after $1 \mathrm{~min}$. Quantification was performed using a Trolox standard curve. The antioxidant capacity of the samples was expressed as milligrams of Tx per liter of sample.

\subsection{Total Polyphenols by Folin-Ciocalteu Assay}

The total polyphenols (TP) of the EDs were determined by the Folin-Ciocalteu assay [27]. First, $0.3 \mathrm{~mL}$ of sample was added to a 10-mL capacity tube, next $0.05 \mathrm{~mL} 2 \mathrm{~mol} / \mathrm{L}$ Folin-Ciocalteu

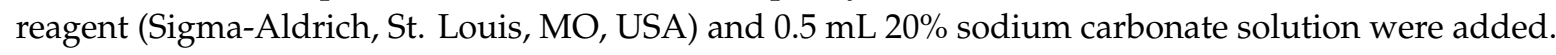
The mixture was diluted by addition of $4.15 \mathrm{~mL}$ distilled water and mixed. The absorbance was measured on a Hitachi U-1900 spectrophotometer at $765 \mathrm{~nm}$ after $30 \mathrm{~min}$ incubation in the dark at room temperature. A calibration curve was performed with gallic acid. The results were expressed as milligrams of gallic acid equivalents (GAE) per liter of sample.

\subsection{Total Anthocyanins}

Total anthocyanins (TA) were determined by the $\mathrm{pH}$ differential method (AOAC Official Method 2005.02). Juices were diluted according to appropriate dilution ratios (1 part sample and 4 parts buffer) by adding both $0.025 \mathrm{~mol} / \mathrm{L} \mathrm{KCl}(\mathrm{pH} 1.0)$ or $0.4 \mathrm{~mol} / \mathrm{L} \mathrm{CH}_{3} \mathrm{COONa} \cdot 3 \mathrm{H}_{2} \mathrm{O}(\mathrm{pH} 4.5)$ buffer solutions (Avantor Performance Materials). Samples were mixed and left in the dark for $30 \mathrm{~min}$. Absorbance was measured on a Hitachi U-1900 spectrophotometer at $520 \mathrm{~nm}$ and $700 \mathrm{~nm}$, and the results were calculated using the following formula:

$$
\mathrm{A}=\left[\left(\mathrm{A}_{520}-\mathrm{A}_{700}\right)_{\mathrm{pH} 1.0}-\left(\mathrm{A}_{520}-\mathrm{A}_{700}\right)_{\mathrm{pH} 4.5}\right]
$$

where $A_{520}$ is the absorbance measured at $520 \mathrm{~nm}$ and $A_{700}$ is the absorbance measured at $700 \mathrm{~nm}$, at $\mathrm{pH} 1.0$ and 4.5 , respectively.

Total anthocyanins were expressed as milligrams of cyanidin-3-mono-glucoside equivalents (CGE) per liter of juice [28].

Molar extinction coefficient $=26.900 \mathrm{~L} / \mathrm{mol} / \mathrm{cm}$ and molecular weight $=449.2 \mathrm{~g} / \mathrm{mol}$.

\subsection{Statistical Analysis}

The results were statistically analyzed by calculating the mean and standard deviation. The interpretation of the results was performed with MS Excel 2010 Analysis ToolPak software 
(Microsoft, Redmond, DC, USA). The conditions of normality and constant variance were satisfied, so we performed the one-way analysis of variance (ANOVA) using the Tukey's post-hoc test: different letters in the same column indicate statistical significance (at least $p<0.05$ ).

\section{Results and Discussion}

Most of the analyzed energy drinks had a typical composition, including $320 \mathrm{mg} / \mathrm{Kg}$ caffeine content. Sample C11 was an exception in that containing $480 \mathrm{mg} / \mathrm{Kg}$ of caffeine. The soluble solids content in the classic EDs was about $120-130 \mathrm{~g} / \mathrm{Kg}$, except sugar-free energy drinks (C12 and C13) (Table 1). The energy drinks with added fruit juices or natural pigments tended to have a higher content of soluble solids, by as much as $20-40 \mathrm{~g} / \mathrm{Kg}$, more than the classic EDs.

The analyzed classic EDs were characterized by low pH, ranged from 3.18 to 3.66 (Table 1). The fruit-enriched EDs had a slightly lower $\mathrm{pH}$, ranged from 2.32 to 3.60. Seven of the ten fruit EDs had a $\mathrm{pH}$ less than 3.0. The high acidity of EDs could be caused mainly by their content of vitamin $\mathrm{C}$. The classic EDs contained $75 \mathrm{mg} / \mathrm{Kg}$ to $150 \mathrm{mg} / \mathrm{Kg}$ of sample (expressed as AA). The fruit EDs had significantly ( $p \leq 0.05$ ) more vitamin $C$, from about $150 \mathrm{mg} / \mathrm{Kg}$ to over $500 \mathrm{mg} / \mathrm{Kg}$ (except samples F9 and F10; Table 2). Furthermore, the low $\mathrm{pH}$ of all EDs was due to the presence of acidity regulator, i.e., citric acid and/or sodium citrate. The content of these acids in EDs increased the antioxidant effect.

In our study, determination of antioxidant capacity was based on DPPH assay, which is very popular in food analyses, especially of fruit, vegetables, and juices [25,29,30]. DPPH assay is a simple and inexpensive method [23], which ensures a high linear correlation with respect to both the content of flavonoids [31] and other methods [24]. Our results showed that EDs with added fruit juices or natural pigments had the highest antioxidant capacity. The samples F2, F3, F4, and F8 were characterized by the highest antioxidant capacity ranged $240-290 \mathrm{mg} / \mathrm{L}$ (expressed as Tx) (Table 2). The remaining fruit EDs had lower values below $200 \mathrm{mg} / \mathrm{L}$. Antioxidant capacity of classic EDs ranged typically from $60 \mathrm{mg} / \mathrm{L}$ to $90 \mathrm{mg} / \mathrm{L}$, the highest value among them was demonstrated by sample C5 (99.0 $\pm 0.4 \mathrm{mg} / \mathrm{L})$. Assay ABTS confirmed the high antioxidant capacity of fruit EDs. Obtained results for fruit EDs ranged from $120.6 \mathrm{mg} / \mathrm{L}$ to $449.0 \mathrm{mg} / \mathrm{L}$ (expressed as Tx), and for classic EDs only from $95.4 \mathrm{mg} / \mathrm{L}$ to $157.4 \mathrm{mg} / \mathrm{L}$. We observed higher results for ABTS assay than DPPH assay. Both radicals (DPPH and ABTS) might have also various affinities to other compounds present in the samples. ABTS radical could react with flavonoids, giving slightly overstated results. The DPPH assay is more reliable and gives more accurate results [32].

Similarly to antioxidant capacity, fruit EDs had the highest total polyphenol concentration, especially F1 and F3 (703.3 $\pm 13.2 \mathrm{mg} / \mathrm{L}$ and $581.0 \pm 5.8 \mathrm{mg} / \mathrm{L}$, respectively; expressed as GAE) (Table 2). These ones had a large contribution of fruit juices in their composition (F3) or anthocyanins (F1), as well as guarana extract (both samples). On the other hand, classic EDs were characterized by lower polyphenols concentration, typically from $115 \mathrm{mg} / \mathrm{L}$ to about $300 \mathrm{mg} / \mathrm{L}$. The exception in that were samples C10 and C11 (above $500 \mathrm{mg} / \mathrm{L}$ ). We noted that samples C10 and C11 had guarana extract additive declared. In our studies, small quantities of total anthocyanin concentration were found in some fruit EDs (samples F1, F3, F5, F6, F8), because those beverages were added with fruit juices naturally rich in them. The highest of total anthocyanins were characterized by F1 and F3 energy drinks $(35.2 \pm 2.0 \mathrm{mg} / \mathrm{L}$ and $30.2 \pm 2.0 \mathrm{mg} / \mathrm{L}$, respectively; expressed as CGE). Smaller amounts of anthocyanin were found in the sample F8 (Table 2). In classic EDs, total anthocyanins were not detected. 
Table 2. Antioxidant properties of various energy drinks.

\begin{tabular}{|c|c|c|c|c|c|}
\hline Sample & $\begin{array}{c}\text { Vitamin C } \\
(\mathrm{mg} / \mathrm{Kg})\end{array}$ & DPPH (mg/L) & ABTS (mg/L) & TP (mg/L) & TA $(\mathrm{mg} / \mathrm{L})$ \\
\hline \multicolumn{6}{|c|}{ Classic energy drinks } \\
\hline $\mathrm{C} 1$ & $107.2^{\mathrm{e}}$ & $73.0 \pm 0.2^{\mathrm{d}}$ & $109.5 \pm 1.9^{d}$ & $158.0 \pm 2.0^{f, g}$ & nd \\
\hline $\mathrm{C} 2$ & $106.9^{\mathrm{e}}$ & $77.0 \pm 0.2^{\mathrm{d}}$ & $119.3 \pm 2.0^{\mathrm{d}}$ & $265.0 \pm 2.4 \mathrm{~d}, \mathrm{e}$ & nd \\
\hline $\mathrm{C} 3$ & $122.4^{\mathrm{d}, \mathrm{e}}$ & $83.0 \pm 0.1^{c, d}$ & $131.1 \pm 2.2^{\mathrm{c}, \mathrm{d}}$ & $290.0 \pm 4.7^{\mathrm{d}}$ & nd \\
\hline $\mathrm{C} 4$ & $75.9^{f}$ & $89.0 \pm 0.3^{c}$ & $142.4 \pm 3.4^{\mathrm{c}}$ & $252.0 \pm 2.5^{\mathrm{e}}$ & nd \\
\hline $\mathrm{C} 5$ & $107.6^{\mathrm{e}}$ & $99.0 \pm 0.4^{\mathrm{c}}$ & $157.4 \pm 2.5^{c}$ & $276.0 \pm 1.8^{\mathrm{d}}$ & nd \\
\hline C6 & $76.7^{\mathrm{f}}$ & $90.0 \pm 0.3^{c}$ & $138.6 \pm 1.8^{\mathrm{c}}$ & $268.0 \pm 3.2^{\mathrm{d}, \mathrm{e}}$ & nd \\
\hline $\mathrm{C} 7$ & $153.5^{\mathrm{d}}$ & $94.0 \pm 0.1^{c}$ & $145.7 \pm 2.1^{\mathrm{c}}$ & $250.0 \pm 3.9^{\mathrm{e}}$ & nd \\
\hline $\mathrm{C} 8$ & $81.1^{\mathrm{f}}$ & $97.0 \pm 0.2^{\mathrm{c}}$ & $155.2 \pm 3.2^{c}$ & $314.0 \pm 1.6^{\mathrm{d}}$ & nd \\
\hline C9 & $141.9^{\mathrm{d}}$ & $72.0 \pm 0.2^{\mathrm{d}}$ & $113.8 \pm 1.2^{\mathrm{d}}$ & $432.0 \pm 1.7^{c}$ & nd \\
\hline $\mathrm{C} 10$ & $142.4^{\mathrm{d}}$ & $83.0 \pm 0.1^{\mathrm{cd}}$ & $132.8 \pm 1.7^{\mathrm{cd}}$ & $590.0 \pm 10.6^{b}$ & nd \\
\hline $\mathrm{C} 11$ & $143.7^{d}$ & $76.0 \pm 0.1^{\mathrm{d}}$ & $120.8 \pm 1.2^{\mathrm{d}}$ & $523.0 \pm 4.6^{\mathrm{b}}$ & nd \\
\hline $\mathrm{C} 12$ & $83.7^{\mathrm{f}}$ & $60.0 \pm 0.3^{d}$ & $95.4 \pm 1.0^{\mathrm{d}}$ & $115.0 \pm 1.8^{h}$ & nd \\
\hline $\mathrm{C} 13$ & $105.8^{\mathrm{e}}$ & $67.0 \pm 0.2^{\mathrm{d}}$ & $107.2 \pm 0.8^{d}$ & $138.0 \pm 3.4^{\mathrm{g}}$ & nd \\
\hline $\mathrm{C} 14$ & $111.6^{\mathrm{e}}$ & $65.0 \pm 0.1^{\mathrm{d}}$ & $103.3 \pm 1.2^{\mathrm{d}}$ & $131.0 \pm 2.5 \mathrm{~g}$ & nd \\
\hline \multicolumn{6}{|c|}{ Fruit energy drinks } \\
\hline $\mathrm{F} 1$ & - & $163.0 \pm 0.1^{b}$ & $261.0 \pm 3.8^{b}$ & $703.3 \pm 13.2^{\mathrm{a}}$ & $35.2 \pm 2.0^{\mathrm{a}}$ \\
\hline $\mathrm{F} 2$ & $301.3^{b}$ & $278.0 \pm 1.4^{\mathrm{a}}$ & $439.2 \pm 12.0^{a}$ & $381.0 \pm 2.0^{c}$ & nd \\
\hline F3 & - & $286.0 \pm 3.4^{\mathrm{a}}$ & $449.0 \pm 11.4^{\mathrm{a}}$ & $581.0 \pm 5.8^{b}$ & $30.2 \pm 2.0^{\mathrm{a}}$ \\
\hline $\mathrm{F} 4$ & $359.0^{\mathrm{b}}$ & $263.0 \pm 0.9^{a}$ & $415.5 \pm 8.2^{\mathrm{a}}$ & $440.0 \pm 9.1^{c}$ & nd \\
\hline F5 & $230.0^{c}$ & $175.0 \pm 1.1^{b}$ & $278.2 \pm 4.0^{b}$ & $202.0 \pm 1.3^{f}$ & $9.6 \pm 1.0^{\mathrm{c}}$ \\
\hline F6 & - & $94.0 \pm 0.4^{\mathrm{c}}$ & $152.2 \pm 2.0^{\mathrm{c}}$ & $139.0 \pm 2.6 \mathrm{~g}$ & $6.8 \pm 1.0^{\mathrm{c}}$ \\
\hline F7 & $520.2^{a}$ & $168.0 \pm 0.5^{b}$ & $277.2 \pm 4.2^{b}$ & $239.0 \pm 4.4^{\mathrm{e}}$ & nd \\
\hline F8 & - & $242.0 \pm 1.0^{\mathrm{a}}$ & $392.0 \pm 7.2^{\mathrm{a}}$ & $316.0 \pm 3.5^{d}$ & $16.4 \pm 1.0^{b}$ \\
\hline F9 & $155.1^{\mathrm{d}}$ & $74.0 \pm 0.3^{\mathrm{d}}$ & $120.6 \pm 1.9^{d}$ & $105.0 \pm 5.4^{h}$ & nd \\
\hline F10 & $153.1^{d}$ & $116.0 \pm 0.1^{c}$ & $189.1 \pm 3.1^{\mathrm{c}}$ & $289.0 \pm 11.2^{\mathrm{d}}$ & nd \\
\hline
\end{tabular}

Data are mean \pm standard deviation $(n=5)$. Different letters in the same row indicate statistical significance (at least $p \leq 0.05$ ). Vitamin C content is expressed as milligrams of ascorbic acid; DPPH—antioxidant activity measured by DPPH method (expressed as milligrams of Trolox equivalents); ABTS—antioxidant activity measured by ABTS method (expressed as milligrams of Trolox equivalents); TP-total polyphenols measured by Folin-Ciocalteu assay (expressed as milligrams of gallic acid equivalents); TA-total anthocyanins measured by the $\mathrm{pH}$ differential method (expressed as milligrams of cyanidin-3-glucoside equivalents); nd-non detected.

The mean values of antioxidant properties for fruit and classic EDs were calculated (Figure 1). Obtained results showed significantly higher values for fruit EDs. The average antioxidant capacity for fruit EDs was $185.9 \mathrm{mg} / \mathrm{L}$, while only $80.4 \mathrm{mg} / \mathrm{L}$ (expressed as Tx) for classic EDs. Similar results were observed in the ABTS assay. The highest antioxidant capacity was characterized by fruit EDs (mean value $297.4 \mathrm{mg} / \mathrm{L}$ ), while for the classic it was much lower (mean value $126.6 \mathrm{mg} / \mathrm{L}$ ). Total polyphenols concentration was also higher for fruit EDs (339.5 mg/L versus $285.9 \mathrm{mg} / \mathrm{L}$; expressed as GAE). Moreover, energy drinks with the addition of fruit juices and natural pigments had a much higher content of vitamin C ( $286.5 \mathrm{mg} / \mathrm{Kg}$ versus $111.5 \mathrm{mg} / \mathrm{Kg}$; expressed as AA). Furthermore, the correlation coefficients were calculated and showed that vitamin $C$ content had a greater impact on antioxidant capacity $\left(r^{2}=0.750\right)$ than total polyphenols concentration $\left(r^{2}=0.431\right)$. 


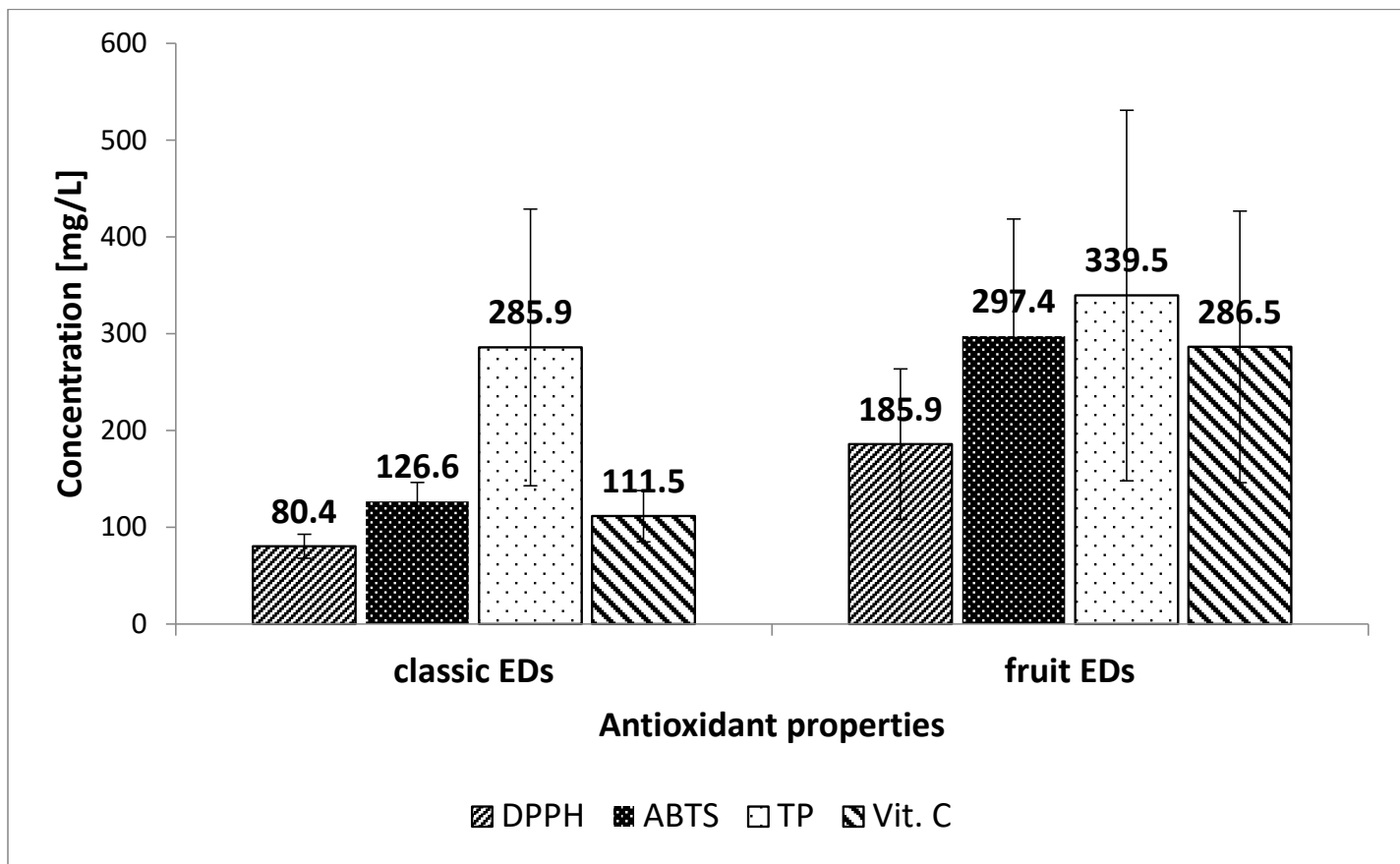

Figure 1. Mean values of antioxidant properties.

The literature data show only few references concerning the determination of antioxidant properties of EDs. Diamantini et al. [33] reported that EDs containing extracts of guarana, ginseng, yerba mate, or caffeine presented higher total polyphenols concentration and higher antioxidant activity than EDs without additives. As reported by McLellan and Lieberman [34], guarana extract contains saponins and tannins, which exert antioxidant effects. In another study done by Witkowska et al. [35], among 11 different EDs, the highest antioxidant capacity, determined by DPPH and FRAP (ferric reducing antioxidant power), was demonstrated by samples with added fruit juices. These samples were also the richest source of polyphenolic compounds, i.e., $147 \mathrm{mg} / \mathrm{L}$ and $195 \mathrm{mg} / \mathrm{L}$, respectively (expressed as GAE) [35]. These authors also found a lower concentration of polyphenols in the classic EDs analyzed, ranging from $60 \mathrm{mg} / \mathrm{L}$ to $90 \mathrm{mg} / \mathrm{L}$ [35]. Our research, in comparison with Witkowska et al. [35], showed a bit higher results for classic EDs, but much higher for fruit EDs (Table 2). Both studies noted no significant differences in total polyphenols between some fruit EDs and classic ones.

Compared to other food products such as plain fruit juices, the analyzed EDs were characterized by relatively poor antioxidant properties. The total polyphenols concentration and antioxidant capacity of energy drinks determined in our research were significantly lower than values which have been found in juices, nectars, and fruit drinks [25,36] or even in teas [37]. EDs should not be considered as a good source of antioxidants. Slightly better antioxidant capacity of fruit EDs may have been caused by the presence of vitamin $C$ and polyphenols derived from the added fruit juice, or from herbal extracts (ginseng, guarana) as well as other additives, e.g., citric acid or ascorbic acid. The slightly higher antioxidant properties of fruit EDs due to the presence of antioxidant compounds could contribute to a small degree to the reduction of oxidative stress.

The results of total anthocyanins concentration showed that the highest amounts of these compounds were samples F1 and F3. The first fruit energy drink had added anthocyanins, and the second apple, black currant, grape, and strawberry juices (Table 1). Other fruit EDs contained anthocyanins because they contained apple juice (F5), apple and pomegranate juices (F6), and acai and goji juices. Classic EDs were characterized by relatively low antioxidant properties. Determined antioxidant capacity of classic EDs was a result of presence of taurine [38] and other antioxidant molecules present in classic EDs. 
The analyzed energy drinks were characterized by considerable amounts of sugar in their composition. One $250 \mathrm{~mL}$ can of energy drink provide as much as $30 \mathrm{~g}$ of sugar. Thus, regular consumption of EDs poses a risk of excessive sugar ingestion, which is conducive to overweight, obesity, and tooth decay. Health risks related to large quantities of sugar in drinks have been reported by numerous researchers. Dawis et al. [39] concluded that high sugar content of EDs can increase the risk of obesity. Others have drawn attention to the dangers of developing type 2 diabetes and dental problems, including enamel erosion [40-42]. Clapp et al. have shown that energy drinks contain excessive amounts of free sugars, ranging from $25.5 \mathrm{~g}$ to $69.2 \mathrm{~g}$. The authors concluded that regular consumption of energy drinks could contribute to dental erosion and the development of obesity [43]. In addition to the presence of sugar in EDs, an additional problem may be the low $\mathrm{pH}$ of drinks could contribute to dental erosion. In our study, the $\mathrm{pH}$ of EDs was from 2.32 to 3.66 and it was the lowest in fruit energy drinks. In another study, all five energy drinks investigated had $\mathrm{pH}$ values below the critical value (5.5) associated with dental erosion [43].

Consumption of EDs fortified with fruit juices or herbal extracts provides some antioxidants compared to classic EDs, however, it still does not solve the problems of associated health risks. EDs contain large amounts of sugar (mainly saccharose), which could contribute to overweight and obesity. Furthermore, excessive consumption of EDs may be associated with a greater risk of cardiovascular disease, due to the synergistic effect of glucose and caffeine $[12,13]$. Previous studies showed that consumption of energy drinks (EDs) rich in caffeine and sugar may have an adverse effect on human health, mainly by raising arterial blood pressure and blood glucose level; in the long-term, it increases the risk of cardiovascular diseases and type 2 diabetes [8,44-46]. The problem increases when the excessive consumption of EDs is combined with the simultaneous consumption of other sources of caffeine, such as coffee or cola-type beverages. This fact concerns especially adolescents and young adults who consume several caffeinated drinks daily. Current knowledge of health risks associated with excessive consumption of EDs is scarce. There are scientific studies that showed the beneficial effects of moderate amounts of caffeine on human health [9-11]. Most of these studies present data on the effects of a daily caffeine intake lower than $600 \mathrm{mg}$ [9] and, moreover, concern plain coffee or extracts containing caffeine, but did not include energy drinks.

\section{Conclusions}

The research results have proven that energy drinks are not a rich source of polyphenols and do not have high antioxidant capacity. Energy drinks containing fruit juices and natural pigments (e.g., anthocyanins) show significantly higher antioxidant properties (total polyphenols concentration and antioxidant capacity) than classic EDs. They also have a higher vitamin C content. It should be noted that energy drinks, especially classic types, are a much poorer source of antioxidants than fruit juices, fruit drinks, or even teas. Moreover, the high content of caffeine and sugar means that EDs should be consumed in moderation. High sugar content and low $\mathrm{pH}$, especially fruit energy drinks, could contribute to dental erosion and the development of obesity. In conclusion, fruit EDs available on the market look like an interesting alternative to classic EDs since the addition of good quality fruit juices (especially from colored berries) may increase the antioxidant capacity. Furthermore, the natural content of sugar of fruit juices could result in a reduction of saccharose or glucose-fructose syrup additives. For the reported reasons, fruit EDs may be a better choice than classic EDs.

Author Contributions: D.N.: conceptualized the study; designed the experiments; collected and analyzed the data; wrote, edited, and revised the manuscript. M.G.: collected and analyzed the data and edited and revised the manuscript. All authors have read and agreed to the published version of the manuscript.

Funding: This research received no external funding.

Conflicts of Interest: The authors declare no conflict of interest. 


\section{References}

1. Higgins, J.P.; Tuttle, T.D.; Higgins, C.L. Energy beverages: Content and safety. Mayo Clin. Proc. 2010, 85, 1033-1041. [CrossRef] [PubMed]

2. Breda, J.J.; Whiting, S.H.; Encarnação, R.; Norberg, S.; Jones, R.; Reinap, M.; Jewell, J. Energy drink consumption in Europe: A review of the risks, adverse health effects, and policy options to respond. Front. Public Health 2014. [CrossRef] [PubMed]

3. Nowak, D.; Jasionowski, A. Analysis of the consumption of caffeinated energy drinks among Polish adolescents. Int. J. Environ. Res. Public Health 2015, 12, 7910-7921. [CrossRef] [PubMed]

4. Seifert, S.M.; Schaechter, J.L.; Hershorin, E.R.; Lipshultz, S.E. Health effects of energy drinks on children, adolescents, and young adults. Pediatrics 2011, 127, 511-528. [CrossRef]

5. Temple, J.L. Caffeine use in children: What we know, what we have left to learn, and why we should worry. Neurosci. Biobehav. Rev. 2009, 33, 793-806. [CrossRef]

6. Worthley, M.I.; Prabhu, A.; De Sciscio, P.; Schultz, C.; Sanders, P.; Willoughby, S.R. Detrimental effects of energy drink consumption on platelet and endothelial function. Am. J. Med. 2010, 123, 184-187. [CrossRef]

7. Brown, I.J.; Stamler, J.; Van Horn, L.; Robertson, C.E.; Chan, Q.; Dyer, A.R.; Huang, C.C.; Rodriquez, B.L.; Zhao, L.; Daviqlus, M.L.; et al. Sugar-sweetened beverage, sugar intake of individuals, and their blood pressure: International study of macro/micronutrients and blood pressure. Hypertension 2011, 57, 695-701. [CrossRef]

8. Grasser, E.K.; Yepuri, G.; Dulloo, A.G.; Montani, J.-P. Cardio-and cerebrovascular responses to the energy drink Red Bull in young adults: A randomized cross-over study. Eur. J. Nutr. 2014, 53, 1561-1571. [CrossRef]

9. Turnbull, D.; Rodricks, J.V.; Mariano, G.F.; Chowdhury, F. Caffeine and cardiovascular health. Regul. Toxicol. Pharmacol. 2017, 89, 165-185. [CrossRef]

10. McAllister, M.J.; Waldman, H.S.; Renteria, L.I.; Gonzalez, A.E.; Butawan, M.B.; Bloomer, R. Acute coffee ingestion with and without medium chain triglycerides decreases blood oxidative stress markers and increases ketone levels. Can. J. Physiol. Pharmacol. 2019. [CrossRef]

11. Chau, Y.-P.; Au, P.C.M.; Li, G.H.Y.; Sing, C.-W.; Cheng, V.K.F.; Tan, K.C.B.; Kung, A.W.C.; Cheung, C.-L. Serum metabolome of coffee consumption and its association with bone mineral density: The Hong Kong osteoporosis study. J. Clin. Endocrinol. Metab. 2019. [CrossRef] [PubMed]

12. Grasser, E.K.; Miles-Chan, L.J.; Charrière, N.; Loonam, C.R.; Dulloo, A.G.; Montani, J.-P. Energy drinks and their impact on the cardiovascular system: Potential mechanisms. Adv. Nutr. 2016, 7, 950-960. [CrossRef] [PubMed]

13. González-Domínguez, R.; Mateos, R.M.; Lechuga-Sancho, A.M.; González-Cortés, J.J.; Corrales-Cuevas, M.; Rojas-Cots, J.A.; Segundo, C.; Schwarz, M. Synergic effects of sugar and caffeine on insulin-mediated metabolomic alterations after an acute consumption of soft drinks. Electrophoresis 2017, 38, 2313-2322. [CrossRef] [PubMed]

14. Bermudez-Soto, M.J.; Tomas-Barberan, F.A. Evaluation of commercial red fruit juice concentrates as ingredients for antioxidant functional juices. Eur. Food Res. Technol. 2004, 219, 133-141. [CrossRef]

15. Wu, X.; Beecher, G.R.; Holden, J.M.; Haytowitz, D.B.; Gebhardt, S.E.; Prior, R.L. Concentrations of anthocyanins in common foods in the United States and estimation of normal consumption. J. Agric. Food Chem. 2006, 54, 4069-4075. [CrossRef] [PubMed]

16. Hernandez-Herrero, J.A.; Frutos, M.J. Colour and antioxidant capacity stability in grape, strawberry and plum peel model juices at different pHs and temperatures. Food Chem. 2014, 154, 199-204. [CrossRef]

17. Sinha, M.; Manna, P.; Sil, P.C. Taurine protects the antioxidant defense system in the erythrocytes of cadmium treated mice. BMB Rep. 2008, 41, 657-663. [CrossRef]

18. Masteikova, R.; Muselik, J.; Bernatoniene, J.; Bernatoniene, R. Antioxidative activity of Ginkgo, Echinacea, and Ginseng tinctures. Medicina 2007, 43, 306-309. [CrossRef]

19. Rubio-Arraez, S.; Capella, J.V.; Castello, M.L.; Ortola, M.D. Physicochemical characteristics of citrus jelly with non cariogenic and functional sweeteners. J. Food Sci. Technol. 2016, 53, 3642-3650. [CrossRef]

20. Polish Standard Committee. Produkty Spożywcze. Oznaczanie Zawartości Witaminy C. (Food Products. the Estimation of Vitamin C); Polish Norm PN-A-04019:1998; Polish Standard Committee: Warsaw, Poland, 1998. (In Polish) 
21. Hallmann, E.; Lipowski, J.; Marszałek, K.; Rembiałkowska, E. The seasonal variation in bioactive compounds content in juice from organic and non-organic tomatoes. Plant Food Hum. Nutr. 2013, 68, 171-176. [CrossRef]

22. Yen, G.; Chen, H.Y. Antioxidant activity of various tea extract in relation to their antimutagenicity. J. Agric. Food Chem. 1995, 43, 27-32. [CrossRef]

23. Apak, R.; Gorinstein, S.; Bohm, V.; Schaich, K.; Ozyurek, M.; Guclu, K. Methods of measurement and evaluation of natural antioxidant capacity/activity (IUPAC Technical Report). Pure Appl. Chem. 2013, 85, 957-998. [CrossRef]

24. Kapci, B.; Neradova, E.; Cizkova, H.; Voldrich, M.; Rajchl, A.; Capanoglu, E. Investigating the antioxidant capacity of chokeberry (Aronia melanocarpa) products. J. Food Nutr. Res. 2013, 52, 219-229.

25. Nowak, D.; Gośliński, M.; Wojtowicz, E. Comparative analysis of the antioxidant capacity of selected fruit juices and nectars: Chokeberry juice as a rich source of polyphenols. Int. J. Food Prop. 2016, 19, 1317-1324. [CrossRef]

26. Re, R.; Pellegrini, N.; Proteggente, A.; Pannala, A.; Yang, M.; Rice-Evans, C. Antioxidant activity applying an improved ABTS radical cation decolorization assay. Free Radic. Biol. Med. 1999, 26, 1231-1237. [CrossRef]

27. Singleton, V.L.; Orthofer, R.; Lamuela-Raventos, R.M. Analysis of total phenols and other oxidation substrates and antioxidants by means of Folin-Ciocalteu reagent. Methods Enzymol. 1999, 299, 152-178. [CrossRef]

28. Lee, J.; Durst, R.W.; Wrolstad, R.E. Determination of total monomeric anthocyanin pigment content of fruit juices, beverages, natural colorants, and wines by the $\mathrm{pH}$ differential method: Collaborative study. J. AOAC Int. 2005, 88, 1269-1278.

29. Samec, D.; Piljac-Zegarac, J. Fluctuations in the levels of antioxidant compounds and antioxidant capacity of ten small fruits during one year of frozen storage. Int. J. Food Prop. 2015, 18, 21-32. [CrossRef]

30. De Abreu, W.C.; Barcelos, M.F.P.; Vilas Boas, E.V.B.; Da Silva, E.P. Total antioxidant activity of dried tomatoes marketed in Brazil. Int. J. Food Prop. 2014, 17, 639-649. [CrossRef]

31. Jakobek, L.; Seruga, M. Influence of anthocyanins, flavonols and phenolic acids on the antiradical activity of berries and small fruits. Int. J. Food Prop. 2012, 15, 122-133. [CrossRef]

32. Arts, M.J.; Haenen, G.R.; Voss, H.P.; Bast, A. Antioxidant capacity of reaction products limits the applicability of the Trolox Equivalent Antioxidant Capacity (TEAC) assay. Food Chem. Toxicol. 2004, 42, 45-49. [CrossRef]

33. Diamantini, G.; Pignotti, S.; Antonini, E.; Chiarabini, A.; Angelino, D.; Ninfali, P. Assessment of antioxidant capacity of energy drinks, energy gels and sport drinks in comparison with coffee and tea. Int. J. Food Sci. Technol. 2015, 50, 240-248. [CrossRef]

34. McLellan, T.M.; Lieberman, H.R. Do energy drinks contain active components other than caffeine? Nutr. Rev. 2012, 70, 730-744. [CrossRef]

35. Witkowska, A.; Zujko, M.E.; Mirończuk-Chodakowska, I. Właściwości przeciwutleniające napojów energetyzujących (Antioxidant properties of energy drinks). Brom. Chem. Toksykol. 2011, 3, 355-360.

36. Seeram, N.P.; Aviram, M.; Zhang, Y.; Henning, S.M.; Feng, L.; Dreher, M.; Heber, D. Comparison of antioxidant potency of commonly consumed polyphenol-rich beverages in the United States. J. Agric. Food Chem. 2008, 56, 1415-1422. [CrossRef]

37. Rusaczonek, A.; Świderski, F.; Waszkiewicz-Robak, B. Antioxidant properties of tea and herbal infusions-A short report. Pol. J. Food Nutr. Sci. 2010, 60, 33-35.

38. Zhang, M.; Izumi, I.; Kagamimori, S.; Sokejima, S.; Yamagami, T.; Liu, Z.; Qi, B. Role of taurine supplementation to prevent exercise-induced oxidative stress in healthy young men. Amino Acids 2004, 26, 203-207. [CrossRef]

39. Davis, M.M.; Gance-Cleveland, B.; Hassink, S.; Johnson, R.; Paradis, G.; Resnicow, K. Recommendations for prevention of childhood obesity. Pediatrics 2007, 120, 229-253. [CrossRef]

40. Clauson, K.A.; Shields, K.M.; McQueen, C.E.; Persad, N. Safety issues associated with commercially available energy drinks. Pharm. Today 2008, 14, 52-64. [CrossRef]

41. Marshall, T.A.; Levy, S.M.; Broffitt, B.; Warren, J.J.; Eichenberger-Gilmore, J.M.; Burns, T.L.; Stumbo, P.J. Dental caries and beverage consumption in young children. Pediatrics 2003, 112, e184-e191. [CrossRef]

42. Pinto, S.C.; Bandeca, M.C.; Silva, C.N.; Cavassim, R.; Borges, A.H.; Sampaio, J.E.C. Erosive potential of energy drinks on the dentine surface. BMC Res. Notes 2013. [CrossRef]

43. Clapp, O.; Morgan, M.Z.; Fairchild, R.M. The top five selling UK energy drinks; implications for dental and general health. Br. Dent. J. 2019, 226, 493-497. [CrossRef]

44. Higgins, J.; Yarlagadda, S.; Yang, B. Cardiovascular complications of energy drinks. Beverages 2015, 1, $104-126$. [CrossRef] 
45. Nowak, D.; Gośliński, M.; Nowatkowska, K. The effect of acute consumption of energy drinks on blood pressure, heart rate and blood glucose in the group of young adults. Int. J. Environ. Res. Public Health 2018, 15, 544. [CrossRef]

46. Ehlers, A.; Marakis, G.; Lampen, A.; Hirsch-Ernst, K.I. Risk assessment of energy drinks with focus on cardiovascular parameters and energy drink consumption in Europe. Food Chem. Toxicol. 2019, 130, 109-121. [CrossRef]

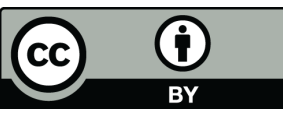

(C) 2020 by the authors. Licensee MDPI, Basel, Switzerland. This article is an open access article distributed under the terms and conditions of the Creative Commons Attribution (CC BY) license (http://creativecommons.org/licenses/by/4.0/). 